\section{MENGENAL ESTETIKA RUPA DALAM PANDANGAN ISLAM}

\section{Martono}

\section{Fakultas Bahasa dan Seni Universitas Negeri Yogyakarta}

\section{Abstrak}

Islam sebenarnya tidak melarang orang berkesenian, justru menganjurkan berseni untuk menuju kebaikan dan keindahan dunia dan akhirat untuk mendekatkan diri kepada Sang Pencipta. Sebagai seorang seniman, pendidik seni bekerja dengan seni, beribadah dengan seni yang sudah geluti selama ini jangan sampai ada karaguan, karena keraguan akan menyesatkan. Untuk mencapai keindahan tertinggi dengan melibatkan latihan spiritual. Sesuai peringkatnya keindahan dapat dibagi menjadi (1) keindahan sensual dan duniawi, yaitu keindahan yang terkait dengan hedonisme dan materialisme, (2) keindahan alam, ciptaan Tuhan (3) keindahan akliah yaitu keindahan yang ditampilkan karya seni yang dapat merangsang pikiran dan renungan, (4) keindahan rohaniah berkaitan dengan ahklak dan adanya pengetahuan tentang hakikat segala sesuatu yang ada dalam diri seseorang atau karya seni, dan (5) keindahan Illahi.

Kata kunci: estetika, seni rupa, dan estetika Islam

\section{PENDAHULUAN}

Dewasa ini masyarakat telah berubah sedemikian rupa sehingga mendapatkan tanggapan pro dan kontra terhap fenomena tersebut, apalagi perubahan itu diakitkan dengan isu bertemunya sains dan agama yang melahirkan kebangkitan spiritual. Munculnya gerakan islamisasi pengetahuan sehingga melahirkan ekonomi islami, psikologi islami, seni islami, dan proses islamisasi yang lainnya. Perubahan itu disebabkan oleh beberapa kekuatan, baik dari dalam maupun dari luar yang menyebabkan menemukan identitas baru disatu pihak dan dipihak lain banyak yang kehilangan identitas dan budayanya. Dunia rupa adalah dunia kreasi yang melahirkan berbagai gagasan yang dapat mengejutkan orang dalam arti kagum dan setuju, kadang pula dapat menimbulkan permasalahan sensitif dalam masyarakat luas. Apalagi permasalahan tersebut berkaitan dengan seni rupa dan pandangan orang Islam terhadap karya seni.

Kebudayaan dalam berproses melibatkan semua komponen yang saling terkait satu sama lain tidak dapat dipisahkan. Antara seniman, penikmat, masyarakat penyangga, pendidikan, dan kebudayaan mempunyai hubungan yang sangat erat. Apabila kebudayaan memiliki tiga unsur penting, yaitu kebudayaan sebagai suatu tata kehidupan (order), kebudayaan sebagai suatu proses, dan kebudayaan yang mempunyai visi tertentu (goals), maka pendidikan dalam proses tersebut sebenarnya merupakan proses pembudayaan. Yang perlu diperhatikan bersama adalah dalam proses berkebudayaan kita berdampingan dengan berbagai kultur dan agama yang harus berjalan berdampingan saling pengertian, saling menghargai, membangun toleransi sehingga semua dapat berkembang bersama secara sinergis dan dalam kedamaian.

Bicara seni juga bicara estetika, seniman dan karyanya. Seni bukan semata-mata sebagai masalah perasaan dan selera pribadi, atau semata-mata bertalian dengan pengalaman sensual. Masalah keindahan dan karya seni bertalian dengan hasrat manusia yang lebih tinggi yaitu pengalaman kerohanian dan kepuasan intelektual. Seni juga berkaitan dengan masalah moral, agama, dan religiusitas. Imam Ghozali menyatakan bahwa efek yang ditimbulkan karya seni terhadap jiwa manusia sangat besar dan oleh karenanya menentukan moral dan penghayatan keagamaan. Apabila masalah estetika hanya dikaitkan dengan selera dan kesenangan sensual, atau kesenangan indrawi, maka nilai seni tersebut akan merosot. Karena itu dalam tradisi Timur seni dipandang sebagai bagian dari kebajikan intelektual dan spiritual. Sedangkan di Barat pandangan sempit terhadap estetika yang memisahkan dari etika, metafisika, dan spritualitas.

Baumgerten memandang estetika sebagai pengetahuan mengenai pengamatan indra, bertentangan dengan tujuan ilmu yang sebenarnya. Menurut Gadamer tujuan pengetahuan yang sebenarnya ialah menyerap kebenaran universal dan mengatasi subjektivitas. Karena itu pengetahuan termasuk estetika, tidak boleh ditentukan hanya oleh kesenangan dan hasil pengamatan indra. Monroe C Beardsley (1968) secara umum kajian estetika mengandung unsur utama yaitu: (1) Pembicaraan tentang hakikat karya seni dan objek-objek indah buatan manusia; (2) Pembicaraan tentang maksud dan tujuan penciptaan karya seni serta bagaimana cara memahami dan menafsirkannya; (3) Mencari tolok ukur penilaian karya seni dengan kaidah tertentu yang memadahi. Tolok ukur bobot dan keindahan karya seni juga harus dikaitkan dengan besar kecilnya kesempurnaan yang ditampilkan karya seni. Selanjutnya ada pertanyaan bagaimana melihat besar kecilnya estetika dalam karya seni? Sebagai jawaban, Para ahli estetika memberikan patokan keindahan karya seni sebagai berikut: (1) Sempurna dilihat dari sudut bobot gagasan, konsep, dan wawasannya; (2) Sempurna dilihat dari besarnya fungsi sebuah karya seni dalam kehidupan manusia; (3) Sempurna dilihat dari sudut nilai-nilai yang ditawarkan karya seni dan relevansinya bagi perkembangan kebudayaan; (4) Sempurna dilihat dari sudut kesesuaian karya seni dengan cita-cita kehidupan dan nilai-nilai kemanusiaan, kerohaniaan yang hendak ditegakan manusia; (5) Sempurna dilihat dari sudut kegunaan. Pada zaman modern bobot dan keindahan karya seni juga sering diukur dari nilai pembaharuannya dan penyimpangan dari konvensi seni yang ada. Pembaruan dan penyimpangan dipandang sebagai satu cara seniman menyampaikan suara tentang perubahan yang berlangsung dalam masyarakat dan kebudayaan pada zamannya. 


\section{KONSEP ESTETIKA DALAM PERSPEKTIF SENI DAN ISLAM}

\section{Estetika dalam Tradisi Islam}

Seorang seniman dalam menciptakan karya seni perlu kebebasan dan kemerdekaan dalam melahirkan imajinasinya. Kebebasan tentunya tidak lepas dari konteks budaya yang melingkupinya. Penciptaan seni rupa tidak hanya mempertimbangkan aspek estetika saja tetapi juga memperhatikan aspek etika sesuai dengan norma budaya yang berlaku dan agama tentunya. Penciptaan seni tidak hanya menjawab kebebasan berekspresi saja tetapi juga memperhatikan masyarakat pendukungnya. Sebagai ilustrasi seperti yang diunkapkan Engincer (1990) menggambarkan perjalanan Muhammad menghasilkan tiga kebebasan, Pertama, pembebasan sosio-kultural, masyarakat Arab dikenal sangat feodal dan paternal yang selalu melahirkan penindasan. Terdapat dua klas sosial yaitu kelas terhormat yang selalu menindas dan kelas budak dan orang miskin yang selalu tertindas. Islam melalui Muhammad tidak lagi mengenal polarisasi kaya-miskin, lamah-kuat, penindas tertindas, dan seterusnya. Kedua, keadilan ekonomi, sejak Qur'an diturunkan menekankan pemerataan dan keadilan untuk semua. Qur'an menganjurkan orang yang berkecukupan menafkahkan sebagaian hartanya kepada fakir miskin (Q.S.2:29). Ketiga, sikap toleransi kepada agama dan kepercayaan lain. Qur'an telah membuat diktum secara tegas tidak ada pemaksaan dalam beragama, (QS.2:256) bagiku agamaku, bagimu agamamu, dan Qur'an telah mengajarkan penghormatan kepada Nabi yang diturunkan Allah ke dunia. Berangkat dari kebebasan itu seniman juga diberikan kebebasan untuk memilih meniti karir sesuai dengan keyakinannya, dan harus saling menghormati, menghargai, dan toleransi kepada sesama umat dan warga pelestari dan pengembang budaya.

Kegiatan penciptaan karya seni digolongkan sebagai kegiatan intelektual yang berhubungan dengan hikmah dan makrifat. Seorang arsitek pelukis, dan pematung ingin mencapai puncak kariernya mestilah mempelajari cabang-cabang ilmu pengetahuan lain seperti metafisika, logika, ilmu fiqih, hadist, tafsir Qur'an, matematika, dan sebagainya. Dalam kaitan khusus dengan seni lukis, seni khat dan seni geometri , pembicaraan estetika dilakukan antara lain oleh Dust Muhammad, Arudi, Reza Abazi dan sebagainya. Estetika Islam yang dikembangkan para sufi itu tidak hanya mempengaruhi karya sastra, tetapi juga arsitek, seni musik gamelan, batik, seni ukir, atau seni rupa pada umumnya. Gema estetika Islam dapat dirasakan pada karya Amir Hamzah, Danarto, Kuntowijoyo, pelukis Ahmad Sadali, AD Firous, Amri Yahya, Amang Rachman, Oesman Efendy. Dalam tradisi Islam istilah yang digunakan untuk keindahan estetik diambil dari Al Qur'an dan hadis yang berbunyi jamal (keindahan batin) dan husn (keindahan zahir). Hadist yang berbunyi "Tuhan itu Maha Indah dan mencintai keindahan" kata yang digunakan dalam hadis ini adalah jamal dan kata tersebut dikaitkan dengan cinta.
Tetapi tidak semua keindahan yang tergolong husn bermakna negatif, karena untuk nama Tuhan yang indah disebut asma al-husna. Keindahan disini dapat dibedakan menjadi keindahan yang bersifat sementara zawahir (fenomenal) dan keindahan yang langgeng atau sejati.

Al Ghazali mengatakan bahwa peringkat keindahan estetis sejajar dengan peringkat pengalaman kesufian. Ia berjalan dari peringkat syariat (formal), melalui peringkat tarekat, menuju hakikat maknawi dan akhirnya makhrifat. Pencapai keindahan tertinggi dengan melibatkan latihan spiritual. Sesuai peringkatnya keindahan dapat dibagi menjadi (1) keindahan sensual dan duniawi, yaitu keindahan yang terkait dengan hedonisme dan materialisme, (2) keindahan alam, ciptaan Tuhan (3) keindahan akliah yaitu keindahan yang ditampilkan karya seni yang dapat merangsang pikiran dan renungan, (4) keindahan rohaniah berkaitan dengan ahklak dan adanya pengetahuan tentang hakikat segala sesuatu yang ada dalam diri seseorang atau karya seni, dan (5) keindahan Illahi.

Keindahan sensual (nafsani) dan duniawi tidak dapat disebut keindahan sejati, karena pengaruhnya banyak negatif dibanding positifnya, seperti mendatangkan kemungkaran dan kesombongan diri. Keindahan sejati dicintai, walaupun tidak menghasilkan keuntungan material atau kesenangan badani. Menikmati keindahan alam danau, pegunungan yang indah misalnya tidak mendatangkan keuntungan material, tetapi dicintai karena menyenangkan, menenagkan, dan menyehatkan jiwa. Kelezatan, kesenangan, kepuasan yang ditimbulkan keindahan sejati menyebabkan jiwa sehat, ahlak bertambah, pengetahuan dan kerarifan meningkat, pengalaman rohani dan religius semakin kaya. Dalam keindahan sejati yaitu keindahan alam, akliyah, rohaniah, dan illahiyah, manusia dapat melihat asal usulnya di alam kerohanian yang diliputi oleh kebaikan, kebenaran, dan kesmpurnaan sesuai ukurannya.

Imam Ghazali melihat keindahan berdasarkan penampakan kesempurnaan dari sudut objek sesuai dengan kualitas kesempurnaan ideal yang sepatutnya ada dalam sebuah objek. Hal ini berlaku dalam sebuah karya seni, yang dicipta dengan maksud dan tujuan berbeda, dan karenanya untuk fungsi yang berbeda pula dan dengan takaran bobot dan mutu yang berbeda pula. Seekor kuda dikatakan indah sesuai sifat dan proporsi tubuhnya yang ideal bagi seekor kuda yang tangkas dan gagah. Sekuntum bunga dikatakan indah karena proporsi dan komposisi unsurnya ideal bagi sekuntum bunga.

Keindahan tertinggi menurut Imam Ghazali adalah menghubungkannya dengan peringkat kebenaran atau pengetahuan yang ada pada karya atau pribadi yang kita nilai indah. Pengetahuan dan kebenaran tertinggi hanya dapat ditangkap melalui indra keenam yaitu penglihatan batin atau hati dan jiwa universal. Sebagai contoh seluruh kehidupan dan pribadi Nabi Muhammad SAW hanya dapat dilihat nilai dan mutu keindahannya melalui indra keenam. Dilihat secara lahiriah Nabi 
adalah manusia biasa karena beliau juga makan, tidur, berumah tangga, dan memiliki keindahan seperti manusia lainnya. Tetapi dilihat dari kehidupan spiritual dan moralnya beliau adalah lebih dari sekedar manusia biasa. Melalui penjelasan tersebut dapat disimpulkan bahwa penglihatan batin sangat penting dalam membangun kehidupan manusia, serta menumbuhkan semangat religius.

Estetika dalam Islam merupakan perjalanan dari bentuk-bentuk (sunah) menuju hakikat segala bentuk ( $\left.m a{ }^{\prime} n a\right)$ dari mana manusia berasal. Dalam tradisi Islam estetika dikaitkan dengan metafisika atau ontologi, pengetahuan dan pemahaman tentang wujud dan peringkat-peringkatnya dari yang zahir sampai ke yang batin. Karya seni dipahami sebagai manifestasi estetika yang paling tinggi yang diharapkan dapat membawa penikmatnya pada tingkatan kearifan yang lebih tinggi. Atau mendorong manusia melakukan pendakian dari yang zahir menuju yang batin, dari alam tasybih yaitu alam dan bentuk yang dapat dicerna indra menuju alam tanzih yaitu alam transidental yang menuntut tajamnya kepekaan penglihatan kalbu.

Sifat Tuhan yang Maha Indah dan merupakan wajah atau penampakanNya ialah al-rahman dan al-rahim. Dengan demikian keindahan karya Tuhan dapat dilihat pada besarnya cinta Tuhan kepada ciptaan-Nya. Dalam menilai karya seni Islam azas cinta dalam diri atau pada manusia sebagai penghasil karya seni ialah kecenderungan akan keimanan, ketakwaan, kebahagiaan dan hasratnya untuk menegakan kebaikan dan menentang segala bentuk keburukan, kejahilan, kezaliman, buruk sangka, dan ketidakadilan. Seni dalam padangan ini tidak lain adalah suatu bentuk ibadah, pengabdian, dan kepasrahan kepada Tuhan.

Apresiasi terhadap karya sufistik saat ini sejalan dengan meningkatnya minat dan perhatian masyarakat terhadaf tasawuf, tetapi tidak diikuti kajian terhadapnya. Terutama kajian mendalam tentang makna dan estetikanya. Dalam sejarah kecendikiawan Islam estetika dan hermenutika merupakan dua bidang ilmu yang tidak terpisahkan, baik dalam penciptaan karya seni maupun dalam telaah karya seni. Dalam pandangan cendekiawan Islam estetika selalu mempunyai kaitan dengan epistimologi, kosmologi, psikologi, dan metafisika terutama seperti yang digagas para filosuf sufi seperti Ibn Sina, Imam Al Ghazali dan sebagainya. Banyak yang menempatkan seni sebagai hiburan yang dangkal, yang kelewatan sehingga menyempurnakan proses pendangkalan budaya. Sekarang seni yang mengambil bentuk bersifat borjuis sebagai misinya bagi kehidupan, ia berada di surga bikinan yang dibangun dibumi untuk memenuhi kesenangan hedonisme yang antara lain meliputi makan, berfoya-foya, dan melampiaskan nafsu rendah. Tolok ukur penting dari seni yang baik ialah penemuan terhadap kepribadian manusia dan penyebab mekarnya kemungkinankemungkinan transenden manusia, yang mengatasi intelek dan logika. Manusia sebagai individu yang mampu menciptakan karya seni bukan hanya makhluk sosial tetapi juga makhluk rohani, sebagai makhluk sosial manusia harus menjalin hubungan sesama manusia dengan seni dan sebagai makhluk rohani harus menghubungkan diri dengan kehendak Illahi. Manusia sebagai mahkluk Tuhan dikatakan bahwa dosa utama manusia adalah lupa. Sifat pelupa dan acuh tak acuh membuat kita terlena dan membangun dunia impian di sekelilingnya, yang membuat lupa akan dirinya dan akan yang seharusnya dikerjakan di dunia ini. Manusia sebagai makhluk theomorfis tujuannya adalah merealisisr sifat-sifat ketuhanan dalam diri manusia, serta mengingatkan bahwa perjalanan hidup ini juga merupakan perjalanan kerohanian.

Estetika seni Islam yang membahas tentang penghargaan bentuk seni seperti seni kaligrafi, seni ragam hias tumbuhan dan geometrik menempati tempat istimewa, sedangkan lukisan dan seni patung realisme dan naturalisme tidak begitu diistemewakan dalam kehidupan Islam. Seni kaligrafi dan lukisan geometri sepenuhnya merupakan hasil abstraksi dan imajinasi manusia. Kecintaan umat Islam terhadap Al Qur'an mendorong pesatnya perkembangan seni kaligrafi dan menjadikan seni kaligrafi sebagai simbol utama seni Islam dan perwujudan paling istimewa dari esteika Islam, demikian juga dalam seni dekorasi. Secara sepintas telah digambarkan kecenderungan estetika dalam Islam yaitu kuatnya sikap penolakan meniru objek luar secara realis dan naturalis. Sikap ini ada kaitannya dengan sikap Islam yang anti berhala atau ikonoklastis. Manusia memang cenderung menyukai bentuk luar dan keindahan lahiriah. Tetapi seseorang yang telah dianugerahi sikap tauchid, maka segala bentuk kesyirikan yang berkembang dalam dirinya akan dapat dibersihkan. Penciptaan seni dalam Islam dengan bentukbentuk yang anti ikonografis dan wataknya sebagai manifestasi zikir dan pujipujian kepada Tuhan yang Esa. Berkarya seni dalam pandangan islam adalah ungkapan ekspresi penyucian diri dari segala bentuk berhala alam yang bersifat bendawi. Dari prinsip itu maka lahirlah seni islam yang bersifat dekoratif menghindari bentuk realis dan naturalis.

\section{Perbedaan Pendapat Tentang Seni dalam Islam}

Dalam perkembangan sejarah kesenian semenjak zaman prasejarah sampai yang mutakhir seperti sekarang ini, kepercayaan atau agama senantiasa merupakan sumber inspirasi yang amat besar bagi seniman dalam berkarya. Agama adalah pembangkit daya cipta yang luar biasa untuk mewujudkan segala sesuatu yang bernilai seni. Akan tetapi pada pertengahan abad $19 \mathrm{M}$ yaitu permulaan abad yang dipengaruhi oleh pikiran dan cita-cita yang romantis dan materialis, maka sifat keagamaan dalam kesenian mulai hendak ditinggalkan orang. Paham ini muncul di Eropa, mereka menganut paham ini tidak mau terikat oleh aturan norma agama dan berpendapat seni harus independen bebas dari segala pengaruh. Paham ini telah menjelma menjadi aliran baru yang disebut "I'art pour 
I'art' atau seni untuk seni, yang kemudian sampai sekarang disebut sebagai sen murni. Menurut paham ini seni diciptakan semata-mata untuk seni, kesenian bukanlah agama dan bukan untuk agama atau kepentingan praktis yang lain. Paham ini pada hakekatnya adalah suatu aspek kebudayaan dari ajaran marxisme, karena lahirnya marxisme dan atheisme di Eropa.

Dengan paham seni untuk seni sebagai konsep penciptaannya, seniman melemparkan selimut keagamaan keluar menuju alam cipta ekspresi pribadi yang luas, bebas, bahkan absolut. Penganut seni untuk seni menjauhkan diri dari apa yang berbau agama, karena menurut mereka agama tidak memberikan kesempatan istimewa bagi mereka untuk melukiskan objek yang menarik dalam arti yang seluas-luasnya. Mereka menghendaki objek yang tak terbatas, sedangkan agama memberikan batasan tertentu dalam kehidupan berkesenian. Oleh karena itu, mereka lari ke alam bebas, dimana mereka dapat berbuat merdeka melukis dan mematung sesuai keinginannya. Oleh sebab itu Islam tidak mengenal seni untuk seni, Islam tidak mengenal seni yang bebas, akan tetapi yang dikenhendaki Islam adalah seni yang "terpimpin" atau terbimbing" dimana norma-norma agama dan susila harus diindahkan dalam cipta seninya.

Sebab terjadinya perbedaan pandangan dan pendapat dalam seni lukis atau pahat dalam Islam, karena tidak adanya batas yang positif dan tegas mengenai dibolehkan atau tidak Islam dalam melukis atau membuat patung yang realis dan naturalis. Dalam Al-Qur'an tidak dijumpai satupun ayat yang melarangnya, tetapi dalam hadist didapati suatu yang mnyinggung masalah ini. Dari situlah timbul perbedaan pendapat dalam bentuk objek dan motif yang dilukis, secara garis besar perbedaan pendapat Islam tentang seni sebagai berikut: Pendapat pertama, Hadis yang melarang seseorang membuat lukisan atau pahatan yang objek atau motifnya menggambarkan mahluk hidup seperti manusia dan binatang. Dalam hadis dikatakan barang siapa yang membuat gambar atau patung mahkluk bernyawa di dunia ini, maka di akhirat nanti ia harus bertanggungjawab memberikan nyawa, dan akhirnya ia mendapat sisksaan dari Tuhan karena ia tidak dapat memberikan nyawa. Menurut paham ini melukis atau mematung yang menggambarkan mahluk hidup berarti dilarang atau hukumnya haram. Oleh sebab itu semua gambar mahkluk bernyawa tidak dibolehkan. Pendapat kedua, boleh membuat gambar mahkluk bernyawa seperti manusia dan binatang, tetapi dengan syarat bentuknya dua dimensi datar seperti foto, gambar, dan lukisan. Kalau bentuk gambar memiliki ukuran tiga dimensi dapat diraba seperti relief dan arca tidak diperbolehkan. Pendapat ketiga, Boleh membuat gambar mahkluk bernyawa dalam bentuk yang plastis, asal saja dalam bentuk atau rupa yang tidak memungkinkan makhluk itu hidup, misal membuat gambar atau patung setengah badan, secara rasional tidak mungkin bisa hidup karena tidak sempurna. Pendapat ini tetap melarang membuat bentuk mahkluk hidup yang sempurna atau utuh, tetapi membuat sebagaian saja akan terlepas dari tuntutan Tuhan di akhirat nanti, karena bentuk sebagian itu tidak mungkin hidup. Pendapat keempat, umat Islam sudah hidup dalam zaman modern baik cara berpikir, bertindak, dan bertauchid kepada Tuhan, maka Islam membolehkan membuat lukisan atau patung mahkluk hidup seperti lukisan orang, binatang, patung pahlawan, patung raja untuk monumen, asalkan bukan patung untuk disembah atau dipercayai memberikan kekuatan tertentu, seperti dalam Al Qur'an disebut dengan Al-Ashnam atau Al-Anshab. Orang Islam tetap diharamkan membuat dan memperjualbelikan patung untuk agama tertentu seperti Bunda Maria, Yesus, dan arca Hindu dan Budha. Adapun larangan itu tegas dinyatakan dalam Al Qur'an berbunyi "Hai orang-orang beriman, sesungguhnya minuman keras, judi, berhala, dan bertenung adalah perbuatan yang keji dari pada perbuatan setan. Sebab itu hendaklah kamu jauhi mudah-mudahan kamu akan mendapat kemenangan.

\section{Memahami dan Menilai Estetika dalam Islam}

Dalam menilai karya seni Islam, asas yang sangat penting adalah cinta dalam diri atau pada manusia, sebagai penghasil karya seni, ialah kecenderungan akan keimanan, ketakwaan, kebahagiaan, dan hasratnya untuk menegakan kebaikan dan ketidakadilan. Seni dalam padangan ini adalah suatu bentuk ibadah dan pengabdian kepada Tuhan Yang Kuasa. Imam Gazhali membagi peringkat keindahan sebagai berikut: (1) keindahan indrawi dan nafsani (sensual) disebut juga keindahan lahir; (2) keindahan imajinatif emotif; (3) keindahan akhliyah atau rasional; (4) keidahan rohaniah atau irfani; (5) keindahan ilahiyah atau transenden. Seorang seniman yang melahirkan karyanya untuk membawa naik penikmatannya dari tatanan keindahan lahiriah menuju tatanan keindahan yang lebih tinggi yang ada diatasnya. Semakin tinggi tatanan keindahan yang disajikan dalam sebuah karya seni, maka semakin dekat dengan hakikat wujud. Penciptaan karya seni dalam Islam bentuknya yang anti ikonografis dan wataknya sebagai manifestasi zikir serta puji-pujian kepada Yang Maha Kuasa, adalah ungkapan penyucian diri dari segala bentuk berhala alam bendawi yang mengarah pada kemusrikan. Sekaligus untuk menyatakan bahwa martabat manusia tidak ditentukan oleh kemahirannya meniru bentuk-bentuk lahir kehidupan, melainkan oleh kreativitas imajinasi dan akal budi menuju kedekatan kepada Illahi.

Berikut disajikan gambaran dunia yang disajikan dalam Al-Qur'an dan pengaruhnya terhadap estetika, khususnya seni rupa dan sastra. Pertama ayat -ayat yang dibentangkan dalam kitab suci sebagai pedoman hidup umat manusia, Kedua ayat-ayat dan peristiwa yang dibentangkan di alam semesta sebagai wahana untuk beriman, hidup, dan pengembangan kebudayaan. Berdasarkan pandangan di atas para Sufi menjelaskan fungsi karya seni sebagai berikut: 
a. Fungsi seni untuk tawajjud yaitu membawa penikmat untuk mencapai keadaan jiwa yang damai (mutmainah) dan menyatu dengan keabadian yang abadi.

b. Fungsi seni sebagai tajarrud yaitu pembebasan jiwa dari alam benda melalui sesuatu yang berasal dari alam benda itu sendiri. Misal suara, bunyi-bunyian, lukisan, gambar dan kata-kata.

c. Fungsi seni sebagai tadzkiya al-nafs yaitu penyucian diri dari pemberhalaan terhadap bentuk-bentuk melalui bentuk-bentuk itu sendiri.

d. Fungsi seni untuk menyampaikan hikmah, yaitu kearifan yang dapat membantu kita bersikap adil dan benar terhadap Tuhan, sesama manusia, dengan alam tempat kita hidup, dan diri kita sendiri.

e. Fungsi seni sebagai sarana menyebarkan gagasan, pengetahuan, informasi yang berguna bagi kehidupan seperti pengetahuan sejarah, geografi, hukum, undang-undang, gagasan keagamaan.

f. Fungsi seni diciptakan sebagai puji-pujian kepada Yang Khalik.

Lukisan dalam manuskrip menarik karena gambar figur umumnya ditampilkan statik, tidak ada gerak dan dua dimensi. Pelukis muslim berusaha menekan ketegangan antara estetika Yunani yang didasarkan pada prinsip "Ars imitatur naturam" (seni meniru alam). Sementara itu, estetika Islam menolak naturalisme. Secara garis besar ciri lukisan seniman Islam adalah sebagai berikut.

a. Figur statik tidak ada gerak.

b. Ada watak individual dalam setiap figur yang digambar, yang ditekankan disini bukan penampilan zahir dari figur tetapi sifat-sifatnya.

c. Terdapat banyak seni dekoratif atau arabesk yang ditambah untuk menggambarkan bahwa manusia hanya dapat hidup di dalam lingkungan alam.

d. Warna dibuat bukan untuk meniru warna alam, tetapi untuk menciptakan keselarasan dalam ruang tertentu.

e. Ruang dibuat vertikal dari atas ke bawah dengan garis spiral, pada akhir yang menentukan kualitas lukisan ialah tatanan atau susunan geometrisnya.

\section{SIMPULAN}

Mengakhiri tulisan ini disampaikan kesimpulan bahwa sebagai umat Islam untuk berkarya seni, menikmati karya diberikan beberapa tawaran yang dapa dipahami atau dipilih untuk proses berkesenian. Islam sebenarnya tidak melarang orang berkesenian, justru menganjurkan berseni untuk menuju kebaikan dan keindahan dunia dan akhirat untuk mendekatkan diri kepada Sang pencipta Sebagai seorang seniman muslim, pendidik seni beribadahlah dengan seni yang kamu geluti selama ini jangan ada karaguan, karena keraguan akan menyesatkan.
Berseni secara Islami untuk ikut membangun budaya keindahan, toleransi, kedamaian bersama dalam masyarakat yang multikultural.

Agar lebih jelas memberikan pemahaman disampaikan watak seni lukis Islam melalui gambaran sebagai berikut. Pertama, orang Islam sangat mencintai $\mathrm{Al}$ Qur'an, hal ini mempengaruhi tumbuhnya kaligrafi. Keindahan dan pesona bahasa Qur'an membuat seniman muslim bergairah menghadirkan kata-kata suci dalam bentuk tulisan indah (khat). Kedua, Islam mempunyai komitmen besar terhadap sejarah, alam hanya menarik sebagai latar belakang kehidupan manusia, sebab tanpa ada manusia alam tidak ada artinya. Ketiga, pelukis Islam tidak memperhatikan perspektif, kecuali lukisan pada zaman Jahangir akhir abad 17 di India dipengaruhi lukisan Belanda dan Belgia. Oleh karena itu dalam Islam jarang dijumpai lukisan tiga dimensi, alasannya jauh dan dekat sama. Keempat, pelukis Islam menolak kegelapan, lukisan mereka penuh limpahan cahaya dan warna cerah, tidak ada yang gelap dalam lukisan. Gelap bukan esensi waktu dan ruang melainkan sesuatu yang ditambahkan untuk menegaskan keberadaan cahaya terang. Apalagi kegelapan adalah lambang keputusasaan, kezaliman, diskriminasi, dan egosentrisme. sedangkan Islam mengajurkan pemeluknya menolak kesemuanya itu. Kelima, lukisan Islam ialah ekspresi gagasan dan perasaan tunggal yaitu "cinta" Semua detail dan objek dibuat untuk menghasilkan nuansa halus. Maka lukisan Islam cenderung bersifat sufistik, maksudnya setiap objek dalam alam dihadirkan sebagai manifestasi dari ilmu dan cinta Tuhan yang tidak terhingga. Keenam, lukisan Islam merupakan ilustrasi terhadap teks atau wacana, baik sastra, pengetahuan, dan sejarah. Fungsi seperti ini sama dengan alam yang merupakan ilustrasi terhadap firman Allah. Ketujuh, setiap waktu seniman muslim mendengar perintah "kun fayakun" dalam berbagai perubahan yang terjadi di sekitarnya. Kedelapan, dunia ini adalah ayat-ayat-Nya atau logos dalam jazat zahir dan dalam gerakan transubtansial yaitu perjalanan menuju substansi kehidupan. Kesadaran seorang muslim berakar dari keinsyafan bahwa antara kata-kata dan fakta atau kenyataan terhadap hubungan imbal balik dan saling memberikan makna. Maka dalam lukisan Islam sering dihadirkan rangkaian kaligrafi berisi ayat Al Qur'an, Hadist, pepatah, puisi, dan sebagainya.

Dengan memahami estetika dalam Islam hendaknya dapat sebagai tambahan wawasan pengetahuan dan sekaligus sebagai refleksi untuk sebuah penyadaran diri dan hati nurani akan petingnya sebagai seorang hamba yang selalu bersyukur dan bertakwa kepadaNya. Dengan seni hendaknya dapat sebagai sarana untuk pembentukan kehalusan budi pekerti dan perilaku yanbg tujuan akhirnya adalah pengabdian dan ibadah dan manyembah kepada Sang Khalik. Sebagai seorang seniman seharusnya beribadah dengan seninya, sebagai seorang pendidik seni beribadah dengan pendidikan seninya, dan sebagai seorang peneliti seni mencari keindahan dan kebenaran melalui seni sebagai ibadahnya. 


\section{DAFTAR PUSTAKA}

Hadi WM, Abdul. 2004. Hermeneutika, Estetika, dan Relegiusitas, esai-esai Sastra Sufistik, dan Seni Rupa. Yogyakarta: Mahatari.

Soleh, A Khudori. 2004. Filsafat Islam. Yogyakarta: Pustaka Pelajar.

Aldin, Alfathri (Editor). 2006. Spriritualitas dan Realitas Kebudayaan Kontemporer. Yogyakarta: Jalasutra.

Takwin, Bagus. 2003. Filsafat timur. Yogyakarta: Jalasutra.

Hilmy, Masdar. 2008. Islam Profetik, Substansi Nilai-nilai Agama dalam Ruang Publik. Yogyakarta: Kanisius

Abdullah, Irwan. 2006. Konstruksi dan Reproduksi kebudayaan. Yogyakarta: Pustaka Pelajar.

Israr C. 1978. Sejarah Kesenian Islam. Jakarta: Bulan Bintang

Kuntowijoyo. 1987. Budaya dan Masyarakat. Yogyakarta: Tiara Wacana.

Rohidi, Rohendi Tjetjep. 2000. Kesenian dalam Pendekatan Kebudayaan. Bandung: STISI Press.

Rohidi, Rohendi Tjetjep. 2001. "Kurikulum Pendidikan Tinggi Seni Rupa dan

Desain: Menegaskan Identitas di Antara Globalisasi dan Lokalitas. Makalah. Bandung STISI

The Liang Gie. 1996. Filsafat Seni Sebuah Pengantar. Yogyakarta: PUBIB 